\title{
Kommentar
}

\section{Et budsjettkutt som ikke er til å leve med}

Energiministeren har kalt sammen til krisemøte i kroppsregjeringen. Han ber de øvrige ministrene om å komme med besparingsforslag på $50 \%$ av energiforbruket fordi det simpelthen ikke er flere kalorier til rådighet. Hjerteministeren er oppbrakt, hans departement kan ikke tåle en slik nedskjæring. Flere andre mener det samme.

Da regjeringen endelig kan starte sine drøftinger, blir de enige om å ta det departement for departement. Hjerteministeren og respirasjonsministeren får gjennomslag for at de må få et mindre kutt enn de andre. Hjerneministeren likeså, til tross for at han har et uforsvarlig stort budsjett. Alle er imidlertid enige om at hvis hjernen slår seg vrang, vil de være ille ute. Men hvor skal de riktig store kuttene tas?

Regjeringen finner at lokomosjonsministeren må kutte helt til beinet - ingen unødvendige bevegelser, ingen lek, ingen løping, ikke engang et smil. Med dette tiltaket har regjeringen spart nesten $30 \%$ av hele energiforbruket.

Noen departementer, som fordøyelse og beinmarg, bruker uforsvarlig mye energi på rask celledeling. I tarmen fornyes tarmepitelet hver tredje dag, på en overflate på størrelse med en ordinær fotballbane. Regjeringen mener det får holde med halvparten så rask celledeling, selv om dette betyr at fotballbanen krymper til volleyballbane. I beinmargen deler cellene seg i meget høy fart, både røde blodceller og alle forsvarsgrener.

Også staben i forsvaret, CD4-cellene, bruker mye energi på celledeling. Her kan det kuttes uten at kroppen umiddelbart går under.
Til slutt blir regjeringen enig om å sende en delegasjon til nabolandene Mamma og Pappa for å be om mer energi. Et slikt budsjettkutt er nemlig ikke til å leve med i det lange løp.

Scenarioet kunne vært hentet fra jenta som beskrives i Klcovansky og medarbeideres kasuistikk eller fra noen av de mange barna man finner på ernæringsavdelingen på barneklinikken ved Ugandas største sykehus, $\mathrm{Mu}$ lago i Kampala. Tidligere var dødeligheten her høyere enn på intensivavdelingen: ett av fire barn kom ikke levende hjem (1).

Underernæring likner mye på pediatrisk aids med aidsdefinerende infeksjoner som for eksempel Pneumocystis jiroveci-pneumoni $(\mathrm{PCP})(2,3)$. Mange av legene så på underernæring som en triviell sykdom, «de manglet jo kun mat». I realiteten er dette meget skjøre pasienter med multiorgansvikt, og de må behandles ekstremt varsomt, særlig $\mathrm{i}$ initialfasen (4).

Når infeksjonsforsvaret ikke får noen ressurser, vil ingen soldater møte invasjonsstyrkene, derfor kommer det ikke til stridigheter. Det blir ikke rubor, calor, dolor eller tumor rundt en infeksjon, og CRP-nivået kan være lavt selv ved sepsis. Dette kan feilaktig fortolkes som at alt er i orden. Isteden må man gi antibiotika i initialfasen til alle barn med underernæring (5).

Kasuistikken gir oss i Norge innsikt i et sykdomsbilde som er altfor alminnelig ute i verden, men uvanlig her hjemme. Noe å lære av.

\section{Thorkild Tylleskär}

thorkild.tylleskar@cih.uib.no
Thorkild Tylleskär (f. 1958) er barnelege og professor ved Senter for Internasjonal Helse, Institutt for global helse og samfunnsmedisin, Universitetet i Bergen.

Forfatter har fylt ut ICMJE-skjemaet og oppgir ingen interessekonflikter.

\section{Litteratur}

1. Bachou H, Tumwine JK, Mwadime RK et al. Risk factors in hospital deaths in severely malnourished children in Kampala, Uganda. BMC Pediatr 2006: 6: 7 .

2. Bachou H Tylleskär T. Downing R et al. Severe malnutrition with and without HIV-1 infection in hospitalised children in Kampala, Uganda: differences in clinical features, haematological findings and CD4+ cell counts. Nutr J 2006; 5: 27.

3. Bachou H, Tylleskär T, Kaddu-Mulindwa DH et al. Bacteraemia among severely malnourished children infected and uninfected with the human immunodeficiency virus-1 in Kampala, Uganda. BMC Infect Dis 2006; 6: 160.

4. Bachou H. Tumwine JK Mwadime RK et al. Reduction of unnecessary transfusion and intravenous fluids in severely malnourished children is not enough to reduce mortality. Ann Trop Paediat 2008: 28: 23-33

5. Guideline WHO. Updates on the management of severe acute malnutrition in infants and children. Genève: World Health Organization, 2013. www. who.int/nutrition/publications/guidelines/ updates management_SAM infantandchildren/ en/index.html (13.1.2014).

Mottatt 3.12. 2013 og godkjent 19.12. 2013. Redaktør: Sigurd Høye.

Engelsk oversettelse på www.tidsskriftet.no 